\title{
MORPHOGENETIC AND STRUCTURAL CHARACTERISTICS OF GAMBA GRASS SUBJECTED TO NITROGEN FERTILIZATION AND DIFFERENT DEFOLIATION INTENSITIES
}

\author{
CARACTERÍSTICAS MORFOGÊNICAS E ESTRUTURAIS DO CAPIM- \\ ANDROPÓGON SUBMETIDO A ADUBAÇÕES NITROGENADAS E INTENSIDADES \\ DE DESFOLHA
}

\begin{abstract}
Sâmara Stainy Cardoso SANCHÊS ${ }^{1}$; Rosane Cláudia RODRIGUES ${ }^{1}$; Ricardo Alves de ARAÚJO ${ }^{1}$; Clésio dos Santos COSTA ${ }^{2}$; Ivone Rodrigues da SILVA ${ }^{3}$; Francisco Naysson de Sousa SANTOS ${ }^{4}$; Marcônio Martins RODRIGUES ${ }^{1}$; Raphael Ramos SILVA ${ }^{1}$

1. Animal Science Department, Federal University of Maranhão, Chapadinha, Brazil. samara-sanches12@hotmail.com; 2. Animal Science Department, Federal University of Ceará, Fortaleza, Brazil; 3. Animal Science Department, Federal University of Piauí, Teresina,Brazil; 4. Animal Science Department, Federal University of Paraíba, Areia, Brazil.
\end{abstract}

\begin{abstract}
This study aimed to evaluate the morphogenetic, structural, and productive characteristics of Andropogon gayanus cv. 'Planaltina' subjected to different nitrogen fertilization levels and defoliation intensities. The experiment was done in a completely randomized design with a factorial arrangement of six nitrogen doses $\left(0,100,200,300,400\right.$, and $\left.500 \mathrm{~kg} \mathrm{~N} \mathrm{ha}^{-1}\right)$ and two defoliation intensities $(15$ and $30 \mathrm{~cm}$ ). The production and structure data were grouped into rainy and dry periods, while morphogenesis data were compared only among different fertilization and defoliation intensities. The total dry forage biomass (TDFB), dry mass of leaves (DML), dry mass of stems (DMS), and dead forage dry mass (DFDM) were then determined. In addition to these variables, the morphogenetic characteristics of the plants and the numbers of tillers alive and dead were evaluated. There was no interaction $(\mathrm{P}>0.05)$ between the effects of nitrogen fertilization doses and the intensity of defoliation on TDFB, DML, DMS, and DFDM in both of the evaluated phases (rainy and dry). It was also observed that the rates of leaf elongation, leaf appearance, and leaf blade elongation increased with nitrogen fertilization. On the other hand, the culm elongation rate and phyllochron decreased as the dose applied increased. The defoliation intensity did not influence $(\mathrm{P}>0.05)$ the morphogenetic characteristics examined, nor did it affect the senescence rate of nitrogen in leaves and number of live leaves per tiller. The number of dead tillers increased linearly during the rainy period. Based on these results, to improve the efficiency of production of gamba grass it is recommended that it be managed with a defoliation intensity of $30 \mathrm{~cm}$ and nitrogen fertilization of $286.52 \mathrm{~kg} \mathrm{~N}^{-1} \mathrm{year}^{-1}$.
\end{abstract}

KEYWORDS: Andropogon gayanus. Dry period. Rainy period. Residue.

\section{INTRODUCTION}

The successful use of pastures depends not only on the availability of nutrients or the grass used, but also onhaving an understanding of the morpho-physiological mechanisms affecting the grass plants and their interactions with the environment and management. In this sense, nitrogen fertilization is a fundamental practice to enhance the production of forage biomass in pastures that are managed intensively.

To understand the responses of plants to nitrogen fertilization and grazing, it is essential that parameters related to their ecophysiology when submitted to different defoliation regimes are evaluated. Ideally, a balance should be found between maintaining sufficient leaf area for photosynthesis and the harvesting of large quantities of leaves before they senesce to encourage the more rational and efficient use of pastures.

To achieve balance between these purposes, two points of great importance must be considered: the first is the amount of fertilizer to be applied, and the second is the residue that is left after grazing. The latter of these factors is important because there is significant flow of carbon to the apical meristems during regrowth, and the former factor acts as an accelerator of this recovery, thus increasing the growth potential of the grass. This flow of carbon is strongly influenced by the processes of nitrogen absorption, partitioning, and recycling, since the use of carbon in activities associated with meristematic morphogenetic processes has been shown to be highly dependent on there being appropriate 
nitrogen nutrient levels. On the basis of this, the interaction between both factors is likely of paramount importance to the survival of the pasture.

In this sense, the grasses in the genus Andropogon are characterized by their great potential for forage production. However, they also feature low to medium nutritive value, accelerated vegetative cycles, and rapid elongation, which thus present limitations and/or difficulties in their ability to be managed under continuous stocking or with rotation, although in general they are used in continuous stocking systems (SERAFIM , 2015). For this reason, there has not been much effort or resources directed at research on these grasses, and thus in the present day, simplistic and generalist recommendations for their use and management still prevail.

In light of the previously observed association between fertilization and defoliation in forage crops, in addition to the importance of nitrogen in plants and its role in several of their morphogenetic characteristics, including the dynamics of leaves and tillers, new studies evaluating gamba grasses and their potential responses to nitrogen fertilization are required. Considering the above, this study aimed to evaluate the morphogenetic, structural, and productive characteristics of Andropogon gayanus Kunth var. bisquamulatus (Hochst) Hack. cv. 'Planaltina', subjected to different nitrogen fertilization levels and defoliation intensities.

\section{MATERIAL AND METHODS}

The experiment done in this study was conducted in the forage crops field of the Department of Animal Science of University of Federal do Maranhão, in Chapadinha, Maranhão, Brazil $\left(03^{\circ} 44^{\prime} 33^{\prime \prime}\right.$ S, 4321'21" W). The municipality of this site is located in the region of the Lower Parnaiba River, at an altitude of $110 \mathrm{~m}$ above sea level, and has a climate of the 'Aw' type, according to the Köppen classification, with moderate wind and moderate to high relative humidity.

The average monthly rainfall and maximum, minimum, and average temperatures during the experimental period are presented in Figure 1. Cumulative rainfall throughout the year was 1315,4 $\mathrm{mm}$, the greatest concentration of which occurred between the months of February to April (INMET, 2013). During the experimental period, the maximum, minimum, and average annual temperatures were around 32,27 , and $23,60^{\circ} \mathrm{C}$ (rainy season) and 35,28 and $23,22^{\circ} \mathrm{C}$ (dry season), respectively.

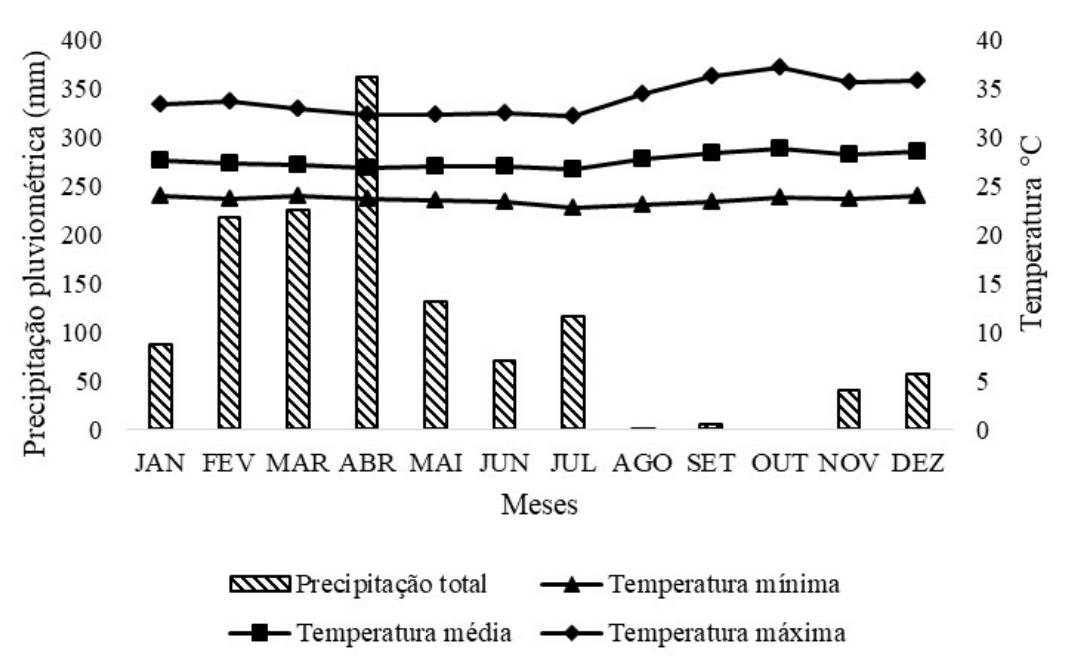

Figure 1. Mean precipitation occurring during the experiment (Source: INMET, 2015).

A completely randomized experimental design was used with a $6 \times 2$ factorial arrangement comprising six doses of nitrogen $(0,100,200,300$, 400 , and $500 \mathrm{~kg} \mathrm{~N} \mathrm{ha}{ }^{-1}$ ) and two defoliation intensities (cutting grass to heights of 15 and $30 \mathrm{~cm}$ ) of Andropogon gayanus Kunth var. bisquamulatus (Hochst) Hack. cv. 'Planaltina', totaling twelve treatments with eight replicate plots of $9 \mathrm{~m}^{2}$ each.
The production and structure data were grouped into two periods, the rainy season (February to June, 2013) and dry season (from July to October, 2013), while the morphogenesis data were only analyzed as a function of the different fertilization levels and defoliation intensities applied. Gamba grass was established in the experimental area used since January, 2012. During the rainy season, three cycles 
of 28 days were evaluated and in the dry period, two cycles of 56 days.

The soil of the experimental site was classified as a yellow latosol (EMBRAPA, 2006), and presented the following chemical characteristics: $\mathrm{pH} \mathrm{CaCl} \mathrm{Cl}_{2}=4.2 ; \mathrm{M} . \mathrm{O} .=19 \mathrm{~g} \mathrm{dm}^{-3} ; \mathrm{P}$ $=5 \mathrm{mg} \mathrm{dm} ; \mathrm{S}=9 \mathrm{mg} \mathrm{dm}{ }^{-3} ; \mathrm{K}=4 \mathrm{mmol}_{\mathrm{c}} \mathrm{dm}^{-3} ; \mathrm{Ca}$ $=50 \mathrm{mmol}_{\mathrm{c}} \mathrm{dm}^{-3} ; \mathrm{Mg}=2 \mathrm{mmol}_{\mathrm{c}} \mathrm{dm}^{-3} ; \mathrm{H}+\mathrm{Al}=29$ $\mathrm{mmol}_{\mathrm{c}} \mathrm{dm}^{-3} ; \mathrm{Al}=8 \mathrm{mmol}_{\mathrm{c}} \mathrm{dm}^{-3} ; \mathrm{CTC}=36 \mathrm{mmol}_{\mathrm{c}}$ $\mathrm{dm}^{-3} ; \mathrm{SB}=7.4 \mathrm{mmol}_{\mathrm{c}} \mathrm{dm}^{-3} ; \mathrm{V}=20 \% ; \mathrm{B}=14,3$ $\mathrm{mmol}_{\mathrm{c}} \mathrm{dm}^{-3} ; \mathrm{Cu}=0.2 \mathrm{mg} \mathrm{dm}{ }^{-3} ; \mathrm{Fe}=55 \mathrm{mg} \mathrm{dm}^{-3}$; $\mathrm{Mn}=0.4 \mathrm{mg} \mathrm{dm}^{-3}$; and $\mathrm{Zn}=0.3 \mathrm{mg} \mathrm{dm}^{-3}$. Liming was performed to lift the base saturation $(\mathrm{V} \%)$, raising the $\mathrm{V}$ from $20 \%$ to $60 \%$. The PRNT (relative power of total neutralization) of the limestone used was $94 \%$. We used the equivalents of $90 \mathrm{~kg} \mathrm{P}_{2} \mathrm{O}_{5} \mathrm{ha}^{-}$ ${ }^{1}$ and $80 \mathrm{~kg} \mathrm{~K}_{2} \mathrm{O} \mathrm{ha}^{-1}$ in the form of super simples and potassium chloride, respectively. The source of phosphorus was applied only once, at the beginning of the experiment, whereas the potassium and nitrogen were applied three times, including soon after the standardization and evaluation cuts were made (February, March and April).

The total dry forage biomass(TDFB), dry mass of leaves (DML), dry mass of stems (DMS), and dead forage dry mass (DFDM) were obtained from the fractionation of material collected in a 0.25 $\mathrm{m}^{2}$ square into leaf, stem and sheath, and dead material for the determination of the production of each of these morphological components. The cutting height inside the square was keptin accordance with the predetermined defoliation intensities $(15$ or $30 \mathrm{~cm})$ used in the experimental plot. The sward height was measured with the aid of a graduated ruler from the base of the soil to the curvature of the last sheath at 30 points per plot. The number of tillers alive (TA) and number of dead tillers (DT) were recorded moments before cutting within a $0.25 \mathrm{~m}^{2}$ square. Sub-samples of the cuts were taken to the laboratory of forage of the Federal University of Maranhão and placed in a forced ventilation oven at $55^{\circ} \mathrm{C}$ until their weight stabilized to determine the percentage of dry matter in them and estimate the production of forage biomass per plot.

For the collection of data on grass morphogenesis, eight plants per plot were marked with colored wires at their bases, and then measurements were made with the use of a ruler twice per week, with the values measured recorded in spreadsheets previously developed for this purpose. Initially, the data were submitted to tests of normality (Cramér-von Mises test) and homoscedasticity (Levene's test), and then after having passed these tests of assumptions they were subjected to analysis of variance (ANOVA) by the F-test. If a significant difference was found, then averages were compared among different treatments using Duncan's test at a 5\% significance level. Statistical analyses were performed with the GLM procedure (with Duncan's test) and PROC REG of the computational program SAS, version 9.3 (SAS INSTITUTE, 2005).

\section{RESULTS AND DISCUSSION}

During the rainy period, there was no interaction effect between cutting intensities and nitrogen doses for TDFB, DML, DMS and DFDM. The TDFB exhibited a quadratic response to nitrogen fertilization $(\mathrm{P}<0.05)$, being maximized $\left(7.83 \mathrm{t} \mathrm{DMha}^{-1}\right)$ at a dose equivalent to $297.39 \mathrm{~kg} \mathrm{~N}$ ha $^{-1}$ (Figure 2).
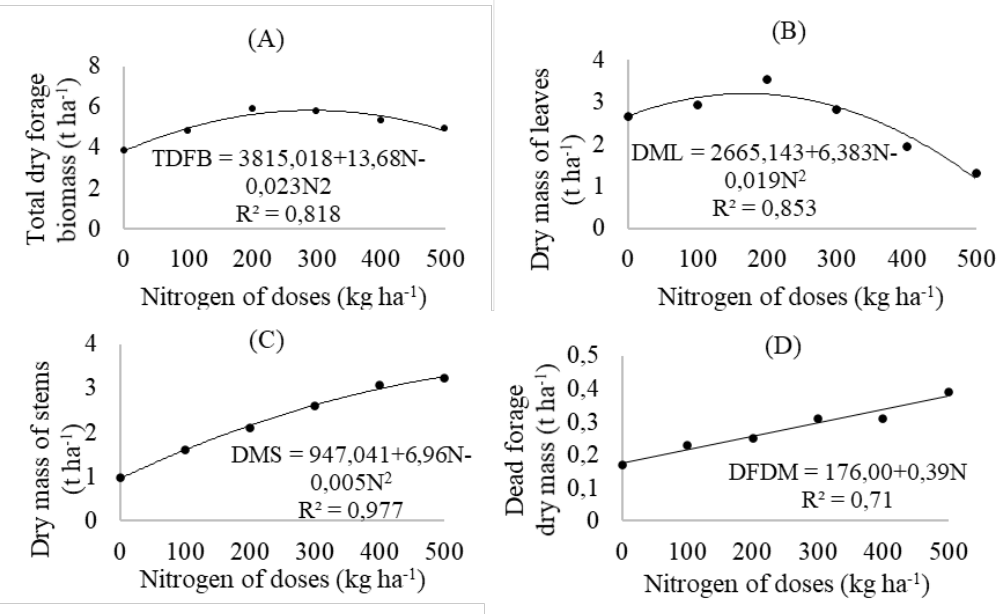

Figure 2. Total dry forage biomass (TDFB), dry mass of leaves (DML), dry mass of stems (DMS) and dead forage dry mass (DFDM) of gamba grass submitted to different defoliation intensities and doses of nitrogen fertilization during the rainy period. 
The TDFB is a basic variable to characterize the production potential of a pasture. Although TDFB increases with the amount of fertilization applied, it should be analyzed with caution because it does not address the qualitative aspects of pasture. For example, the TDFB increases as the time allowed for the grass to regrow increases, but this increase in production is not directly related to the quality of the pasture since, from a certain point onward, the increase in production in $\mathrm{C}_{4}$ grasses, even in the vegetative stage, is due in large part to the accumulation of stems rather than leaves (CÂNDIDO et al., 2005).

For DML and DMS, a quadratic effect was observed, DML obtained maximum production (3.73 t DM ha-1) with a dose of $167.97 \mathrm{~kg} \mathrm{~N}$ ha-1, however, there was a large share of stem. This shows that the increase in TDFB due to fertilization was mainly due increases in stem production, which does not agree with the previously discussed expectations. Furthermore, we observed that there was an increase in TDFB at the highest dose of nitrogen applied. The greater availability of nitrogen accelerates the metabolism of the plant, which
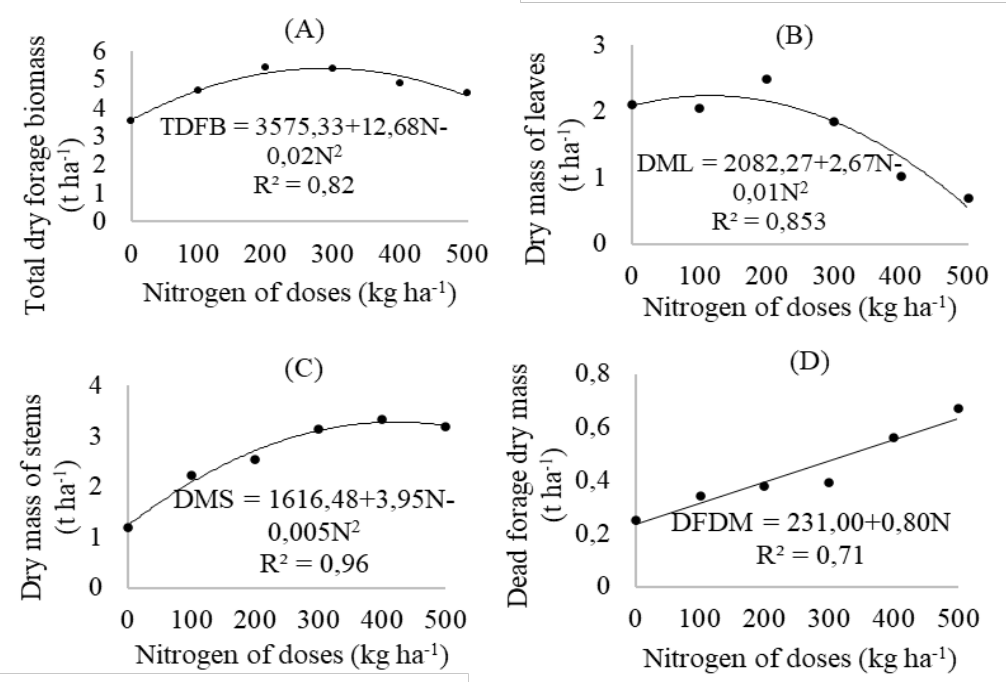

Figure 3. Total dry forage biomass (TDFB), dry mass of leaves (DML), dry mass of stems (DMS) and dead forage dry mass (DFDM) of gamba grass submitted to different defoliation intensities and doses of nitrogen fertilization during the dry period

It is interesting to observe that during the dry period, as well as in the rainy period, there was more production of stems than leaves, showing once again that the highest fertilization level applied to the gamba grass provided large increases in stem production. The leaf/stem ratio is a variable of great importance for estimating the forage intake by grazing animals and for the management of pastures by virtue of its being associated with the ease with which the animals can reap better-quality forage (i.e. leaves) (BRÂNCIO et al., 2003). The low increases forage losses by the acceleration of maturity and senescence in leaves that are formed first in response to the increase in competition for assimilates.

It was observed that the TDFB during the dose applied (Figure 3). However, the maximum production was achieved with the application of $275.65 \mathrm{~kg} \mathrm{~N} \mathrm{ha}^{-1}$ (7.03 t MS ha $\left.{ }^{-1}\right)$. The largest production of leaves occurred with the application of $133.50 \mathrm{~kg} \mathrm{~N} \mathrm{ha}^{-1}\left(2.43 \mathrm{t} \mathrm{MS} \mathrm{ha}^{-1}\right)$. Despite the low rainfall during the dry months, the rains persisted until July, which may have favored the soil in maintaining sufficient moisture for the growth of the grass in the following months. However, there was a greater participation of dead material and less leaves in the TDFB. This change in the morphological composition is a specific mechanism of the plant in limiting the breathable area and dealing with water deficiency, which include the reduction of the leaf area accelerating the senescence of older leaves (FAGUNDES et al. 2006). dry period presented a quadratic response to the $\mathrm{N}$ 
cutting intensities (Figure 4), with a maximum dose of 219.9 and $270.75 \mathrm{~kg}$ of $\mathrm{N} \mathrm{ha}^{-1}$ for the intensity of $15 \mathrm{~cm}$ in the rainy and dry periods, respectively. While for the intensity of $30 \mathrm{~cm}$, the maximum dose that provided the largest number of live tillers was 213.83 and $258.16 \mathrm{~kg}$ of $\mathrm{N} \mathrm{ha}^{-1}$ for the rainy and dry period. It is observed that regardless of the cutting intensity, the grass required a lower dose of $\mathrm{N}$ to maintain a greater number of live tillers during the rainy season. This behavior is related to the greater availability of water (Figure 1). In work developed by Magalhães et al. (2013), when evaluating gamba grass under irrigation and nitrogen doses, shows that even at high nitrogen dosages, the lower water availability in the soil does not allow greater absorption of this nutrient by plants.
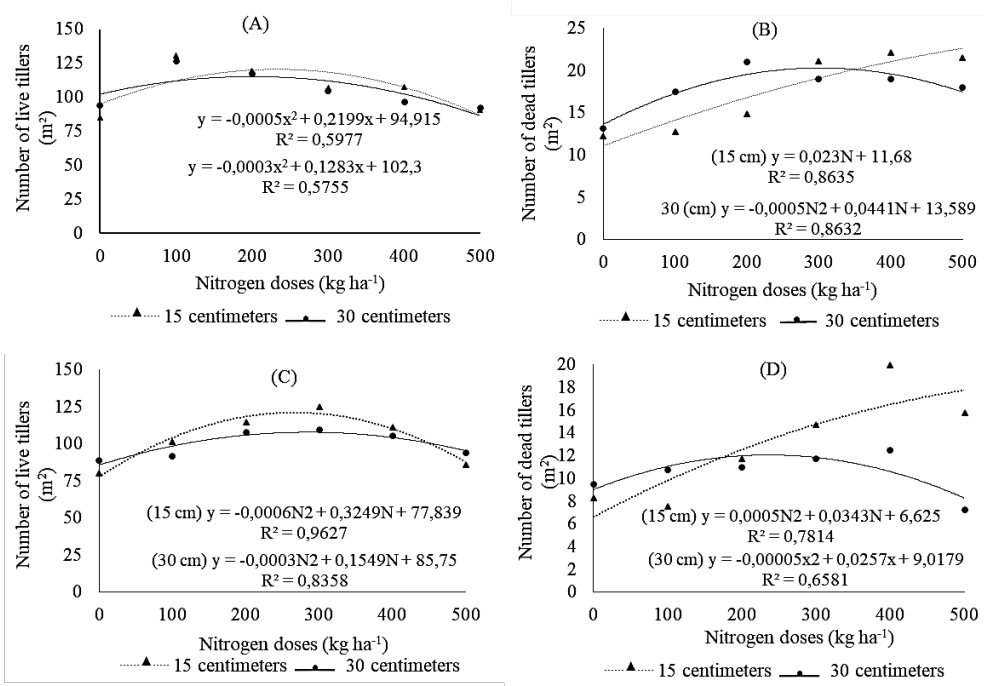

Figure 4. Number of tillers alive during the rainy period (A), tiller number killed during the rainy period (B) number of tillers alive during the dry season $(C)$ and the number of dead tillers during the dry period (D) of gamba grass submitted to different cutting heights and nitrogen fertilization

This response in the number of dead tillers during the rainy period when supplied with increasing doses of nitrogen corroborated the behavior of this variable previously observed in a study of Brachiaria decumbens (MORAIS et al., 2006), Andropogon gayanus (SOUSA et al., 2010), Brachiaria brizantha (SILVA et al., 2013) subjected to nitrogen fertilization, which may have been related to the action of this nutrient in promoting greater plant density, resulting in more dense pasture. This would result in consequent decreases in the penetration of light, favoring greater shading, which would increase the mortality rate of tillers in the pasture due to a lack of carbon supply generated by competition for light, in spite of these plants having passed through a more drastic cut $(15 \mathrm{~cm})$.

This also emphasizes the indirect effect of nitrogen on the mortality of tillers on the pasture, in that $\mathrm{N}$ fertilization may trigger more intense competition for nutrients in general, which stimulates the 'turnover' of tissues. As shown by Moreira et al. (2009), this competition can then cause the mortality of older tillers, which will contribute to the emergence of new ones through the remobilization of nutrients. The defoliation intensity of $30 \mathrm{~cm}$ presented lower tillering, possibly due to there being greater shading at the bases of the plants, which inhibited the tillering of the gamba grass and thus reduced the number of vegetative tillers produced.

The leaf elongation rate (LER) increased with the nitrogen dose, but there was no interaction $(\mathrm{P}>0.05)$ between dose and cut intensity for this variable (Table 1), the highest LER was observed from the application $400 \mathrm{~kg}$ of nitrogen ha-1 (LER = $5.05 \mathrm{~cm} \mathrm{day}{ }^{-1}$ ) and the lowest LER value in the absence of fertilization. The LER values observed for plants that received nitrogen fertilization were higher than that observed by Magalhães et al. (2013), who reported that fertilization had a quadratic effect on the LER of gamba grass, with the maximum value estimated to be $3.24 \mathrm{~cm}_{\text {day }}{ }^{-1}$ with the application of $615.6 \mathrm{~kg} \mathrm{~N} \mathrm{ha}^{-1}$.

Castagnara, et al. (2014) when evaluating the morphogenic characteristics of three tropical grasses (Panicum maximum cvs. Tanzânia and Mombasa, and Brachiaria sp. cv. Mulato) under nitrogen fertilization, observed that the highest dose of $\mathrm{N}$ increased the leaf elongation rate by $3.0 \mathrm{~cm} /$ day $(0 \mathrm{~kg} / \mathrm{ha})$ to $3.99 \mathrm{~cm} /$ day $(160 \mathrm{~kg} / \mathrm{ha})$, representing an increase of $25 \%$ for all species 
evaluated. This behavior was similar to that of the present work, it is observed that, the LER of the plants with the dose of $400 \mathrm{~kg}$ of $\mathrm{N} \mathrm{ha}^{-1}$ and without nitrogen fertilization, there was an increase of $29 \%$ in the LER.

Table 1. Leaf elongation rate (LER), stem elongation rate (SER) of gamba grass submitted to different defoliation intensities and nitrogen fertilization.

\begin{tabular}{|c|c|c|c|c|c|c|c|c|c|c|}
\hline \multirow{3}{*}{$\begin{array}{l}\text { Height } \\
(\mathrm{cm})\end{array}$} & \multicolumn{6}{|c|}{ Dose $\left(\mathrm{kg}\right.$ of $\left.\mathrm{N} \mathrm{ha}^{-1}\right)$} & \multirow{3}{*}{ Mean } & \multirow{2}{*}{\multicolumn{3}{|c|}{ P-value }} \\
\hline & 0 & 100 & 200 & 300 & 400 & 500 & & & & \\
\hline & \multicolumn{6}{|c|}{ LER $\left(\mathrm{cm} \mathrm{day}^{-1}\right)$} & & $\mathrm{N}^{1}$ & $\mathrm{I}^{2}$ & $\mathrm{NxI}^{3}$ \\
\hline 15 & 3,33 & 4,4 & 5,06 & 4,09 & 4,42 & 4,23 & 4,25 & & & \\
\hline 30 & 3,83 & 4,71 & 4,06 & 3,95 & 5,69 & 5,44 & 4,61 & 0,009 & 0,251 & 0,285 \\
\hline \multirow[t]{2}{*}{ Mean } & $3,58 b$ & $4,55 \mathrm{ab}$ & $4,56 \mathrm{ab}$ & $4,02 \mathrm{ab}$ & $5,05 \mathrm{a}$ & $4,83 \mathrm{a}$ & & & & \\
\hline & \multicolumn{6}{|c|}{ SER $\left(\right.$ cm day $\left.^{-1}\right)$} & & \multirow{4}{*}{0,007} & \multirow{4}{*}{0,203} & \multirow{4}{*}{0,218} \\
\hline 15 & 0,60 & 1,32 & 1,06 & 0,78 & 0,87 & 0,93 & 0,93 & & & \\
\hline 30 & 1,09 & 0,99 & 0,82 & 0,60 & 0,67 & 0,58 & 0,79 & & & \\
\hline Mean & $0,84 \mathrm{ab}$ & $1,15 \mathrm{a}$ & $0,94 \mathrm{ab}$ & $0,69 b$ & $0,77 b$ & $0,75 b$ & & & & \\
\hline
\end{tabular}

The effect of nitrogen on LER seems to be related to the availability of this nutrient at the beginning of the development of the leaf primordium, as it is preferentially deposited in the leaf elongation zone, which is protected by a set of the sheaths of older leaves and the pseudostem (GARCEZ NETO et al., 2002). The same authors affirmed that the increase in the size of the leaf blade can be explained both by nitrogen fertilization, which significantly increases the number of cells dividing, and the cutting height, whichal lows the leaf sheath to attain a greater length.

We observed effect $(\mathrm{P}<0.05)$ of nitrogen fertilization on the stem elongation rate (SER), but no effect of defoliation intensity or the interaction between factors on this variable $(\mathrm{P}>0.05)$. The plants fertilized with $100 \mathrm{~kg} \mathrm{~N} \mathrm{ha}^{-1}$ showed a higher SER than others $\left(1.15 \mathrm{~cm} \mathrm{day}^{-1}\right)$. It is interesting to observe that the SER responded inversely to LER, as doses de 400 e $500 \mathrm{~kg}$ de $\mathrm{N}^{-1}$ provided higher LER and lower SER values, which is desirable because the nutritive value of leaves of Poaceae is better than that of the culm. The elongation of the stem is, in a way, a measure of the potential animal performance when grazing on forage because it undermines the structure of the pasture by elevating the apical meristem, with its consequent decapitation by defoliation or trampling by animals. It is worth mentioning that the etiolation of grasses also limitsthe voluntary intake of dry matter by animals (ARAÚJO et al., 2016b), mainly by the concentration of undesirable chemical fractions and the resultant chemical composition being poorer for such forage than that of the leaf blades, meaning that shaded plant parts present lower quality food for animals (DIFANTE et al., 2009). However, the controlled management of the elongation of stems should be done within the limits of tolerance of the forage plant to defoliation, so as not to jeopardize the persistence of the pasture; therefore, the importance of the adoption of management practices that aim at its control must be highlighted.

The leaf appearance rate (LAR) and the phyllochron were influenced $(\mathrm{P}<0.05)$ by nitrogen fertilization (Table 2), but there was no effect of the defoliation intensity and/or the interaction between factors on these $(\mathrm{P}>0.05)$. It was observed that plants that did not receive nitrogen fertilization presented lower LAR values (0.08 leaf day $\left.^{-1}\right)$, whereas from the dose of $100 \mathrm{~kg}$ of $\mathrm{N} \mathrm{ha}^{-1}$, LAR increased to 0.10 leaf $\mathrm{dia}^{-1}$ (Table 2). Generally, light and temperature are the factors that most strongly affect the LAR, but this variable can also be influenced by soil water availability and nitrogen fertilization (ZANINE et al., 2007).

The phyllochron was larger for grass that did not receive nitrogen fertilization $(13,85$ days leaf ${ }^{-1}$ ), whereas among $\mathrm{N}$ doses, a similar reduction was observed. The phyllochronis the inverse of the leaf appearance rate, and indicates the amount of time (in days or degree-days) required for the appearance of two consecutive sheaths. The reduction of the phyllochron with nitrogen fertilization is in agreement with other authors whose works showed a reduction in the phyllochron with nitrogen fertilization (GARCEZ NETO et al., 2002; ALEXANDRINO et al., 2004; MOSQUE; NERES, 2008). Lavres Jr. et al. (2004), in a study of aruana grass fertilized with six doses of $\mathrm{N}$, observed that after 35 days of growth the phyllochron ranged from 2.02 to 0.75 days sheet ${ }^{-1}$ when the dose of $\mathrm{N}$ 
was increased from 14 to $210 \mathrm{mg}$, with there being better results at higher $\mathrm{N}$ doses.

Table 2. Leaf appearance rate (LAR) and Phyllochron of gamba grass submitted to diferente defoliation intensities and nitrogen fertilization.

\begin{tabular}{|c|c|c|c|c|c|c|c|c|c|c|}
\hline \multirow{3}{*}{$\begin{array}{l}\text { Height } \\
(\mathrm{cm})\end{array}$} & \multicolumn{6}{|c|}{ Dose $\left(\mathrm{kg}\right.$ of $\left.\mathrm{N} \mathrm{ha}^{-1}\right)$} & \multirow{3}{*}{ Mean } & \multirow{2}{*}{\multicolumn{3}{|c|}{ P-value }} \\
\hline & 0 & 100 & 200 & 300 & 400 & 500 & & & & \\
\hline & \multicolumn{6}{|c|}{ LAR leafday $^{-1}$ ) } & & $\mathrm{N}^{1}$ & $\mathrm{I}^{2}$ & $\mathrm{NxI}^{3}$ \\
\hline 15 & 0,08 & 0,11 & 0,11 & 0,08 & 0,10 & 0,09 & 0,09 & \multirow{2}{*}{0,005} & \multirow{2}{*}{0,401} & \multirow{2}{*}{0,298} \\
\hline 30 & 0,08 & 0,09 & 0,09 & 0,09 & 0,09 & 0,10 & 0,09 & & & \\
\hline \multirow[t]{2}{*}{ Mean } & $0,08 b$ & $0,10 \mathrm{a}$ & $0,10 \mathrm{a}$ & $0,09 \mathrm{ab}$ & $0,09 \mathrm{ab}$ & $0,10 \mathrm{a}$ & & & & \\
\hline & \multicolumn{6}{|c|}{ Phyllochron (leaves ${ }^{-1}$ days) } & & \multirow{4}{*}{0,004} & \multirow{4}{*}{0,955} & \multirow{4}{*}{0,589} \\
\hline 15 & 14,17 & 10,63 & 9,77 & 13,05 & 11,89 & 11,44 & 11,83 & & & \\
\hline 30 & 13,53 & 12,21 & 11,32 & 11,66 & 11,53 & 10,52 & 11,79 & & & \\
\hline Mean & $13,85 \mathrm{a}$ & $11,42 b$ & $10,55 \mathrm{~b}$ & $12,36 \mathrm{~b}$ & $11,71 b$ & $10,98 b$ & & & & \\
\hline
\end{tabular}

${ }^{1}$ Dose of nitrogen; ${ }^{2}$ defoliation intensity; ${ }^{3}$ Interaction between dose of nitrogen and intensities. Means followed by the same letter, upper case in columns and lower case in rows, do not differ by Duncan test $(\mathrm{P}>0.05)$.

The reduction in the phyllochron by nitrogen fertilization is due to the effect of nitrogen on growth rates, especially in the grass leaf. Nitrogen fertilization allows there to be agreater spare capacity for tissue production since, after defoliation, a quick recovery of the photosynthetic apparatus allows for individuals to have greater competitive ability in the plant community. Nitrogen thus has an extremely important role in encouraging this recovery, since it is an essential nutrient in several physiological processes.

There was no significant main effect $(\mathrm{P}>0.05)$ of different doses of nitrogen or defoliation intensities on leaf senescence rates (Table 3 ). Fagundes et al. (2006), when evaluating Brachiaria decumbens, also observed no effect of nitrogen on leaf senescence. These authors attributed this lack of an effect to the fact that their different $\mathrm{N}$ treatments were applied to pastures that had received the same pasture management and were initially kept at the same height $(20 \mathrm{~cm})$, which also occurred in the present study but at an even greater height $(30 \mathrm{~cm})$. Regarding the senescent leaves, when the pasture is managed under continuous stocking, there is a decrease in the shading of leaves located in the lower strata of the pasture. This shading prevents the process of photosynthesis and favors the senescence of leaves located in this stratum, a common occurrence when the pasture is managed under intermittent stocking.

Table 3. Leaf senescence rate (LSR) and leaf lifespan (LL) of gamba grass submitted to different defoliation intensities and nitrogen fertilization.

\begin{tabular}{|c|c|c|c|c|c|c|c|c|c|c|}
\hline \multirow{3}{*}{ Height (cm) } & \multicolumn{6}{|c|}{ Dose $\left(\mathrm{kg}\right.$ de $\left.\mathrm{N} \mathrm{ha}^{-1}\right)$} & \multirow{3}{*}{ Mean } & \multirow{2}{*}{\multicolumn{3}{|c|}{ P-value }} \\
\hline & 0 & 100 & 200 & 300 & 400 & 500 & & & & \\
\hline & \multicolumn{6}{|c|}{ LSR $\left(\mathrm{cm} \mathrm{day}^{-1}\right)$} & & $\mathrm{N}^{1}$ & $\mathrm{I}^{2}$ & $\mathrm{NxI}^{3}$ \\
\hline 15 & 1,14 & 1,59 & 1,08 & 1,36 & 1,26 & 1,11 & 1,26 & 0005 & 0.401 & 0298 \\
\hline 30 & 1,17 & 0,93 & 1,16 & 0,75 & 0,84 & 1,42 & 1,04 & & 0,401 & 0,290 \\
\hline \multirow[t]{2}{*}{ Mean } & $1,15 \mathrm{a}$ & $1,26 \mathrm{a}$ & $1,12 \mathrm{a}$ & $1,05 \mathrm{a}$ & $1,05 \mathrm{a}$ & $1,27 \mathrm{a}$ & & & & \\
\hline & \multicolumn{6}{|c|}{ LL (days leaf ${ }^{1}$ ) } & & \multirow{4}{*}{0,004} & \multirow{4}{*}{0,955} & \multirow{4}{*}{0,589} \\
\hline 15 & 28,48 & 26,73 & 26,75 & 30,68 & 30,70 & 21,32 & 27,44 & & & \\
\hline 30 & 26,42 & 32,08 & 31,03 & 30,59 & 25,84 & 25,13 & 28,51 & & & \\
\hline Mean & 27,45 & $29,40 \mathrm{a}$ & $28,59 a$ & $30,63 a$ & $28,27 \mathrm{a}$ & $23,22 b$ & & & & \\
\hline
\end{tabular}

${ }^{1}$ Dose of nitrogen; ${ }^{2}$ defoliation intensity; ${ }^{3}$ Interaction between dose of nitrogen and intensities. Means followed by the same letter, upper case in columns and lower case in rows, do not differ by Duncan test $(\mathrm{P}>0.05)$.

The leaf lifespan (LL) was influenced $(\mathrm{P}<0.05)$ by nitrogen fertilization. It was observed that the highest dose of nitrogen led to there being a longer LL (23.22 days leaf $\left.{ }^{1}\right)$. The mechanism by which nitrogen prolongs the lifespan of a leaf can be associated with a higher $\mathrm{N}$ supply allowing the maintenance of higher photosynthetic capacity for longer periods, without significant internal remobilization of $\mathrm{N}$ in older leaves. This behavior can be better understood if analyzed in conjunction with the process of leaf senescence (GARCEZ NETO et al., 2002). Once senescence is established, 
a large part of the nitrogen in a leaf ends up being remobilized to younger leaves, which can contribute significantly to the reduction of the photosynthetic activity of older leaves.

No interaction effect $(\mathrm{P}>0.05)$ was observed between cutting intensities and $\mathrm{N}$ doses for the Final leaf length (FLL) and number of live leaves per tiller (NLLT) (Table 4). Regarding the N doses, the highest FLL was observed when the grass received $400 \mathrm{~kg}$ of $\mathrm{N} \mathrm{ha}{ }^{-1}$. This effect of nitrogen fertilization on the FLL, a reflection of the stimulation of growth by $\mathrm{N}$ associated with a significant increase in the flow of materials among plant organs (DURU; DUCROCQ, 2000) provided by this nutrient, was reflected as an increase in the growth at the end of the leaf sheet (POMPEU et al., 2010), with the consequent increase of the leaf area.

Table 4. Final leaf length (FLL) and number of live leaves per tiller (NLLT) of gamba grass submitted to different defoliation intensities and nitrogen fertilization

\begin{tabular}{|c|c|c|c|c|c|c|c|c|c|c|}
\hline \multirow{3}{*}{ Height (cm) } & \multicolumn{6}{|c|}{ Dose $\left(\mathrm{kg}\right.$ of $\left.\mathrm{N} \mathrm{ha}^{-1}\right)$} & \multirow{3}{*}{ Mean } & \multirow{2}{*}{\multicolumn{3}{|c|}{ P-value }} \\
\hline & 0 & 100 & 200 & 300 & 400 & 500 & & & & \\
\hline & \multicolumn{6}{|c|}{ FLL $(\mathrm{cm})$} & & $\mathrm{N}^{1}$ & $\mathrm{I}^{2}$ & $\mathrm{NxI}^{3}$ \\
\hline 15 & 31,17 & 36,11 & 38,04 & 39,90 & 40,27 & 39,13 & 37,43 & \multirow{2}{*}{0,003} & \multirow{2}{*}{0,119} & \multirow{3}{*}{0,321} \\
\hline 30 & 37,67 & 48,12 & 35,18 & 37,74 & 46,47 & 45,47 & 41,77 & & & \\
\hline \multirow[t]{2}{*}{ Mean } & $34,42 b$ & $42,11 \mathrm{ab}$ & $36,61 \mathrm{ab}$ & $38,82 \mathrm{ab}$ & $43,37 \mathrm{a}$ & $42,30 \mathrm{ab}$ & & & \multirow{5}{*}{0,826} & \\
\hline & \multicolumn{6}{|c|}{ NLLT (leaves tiller ${ }^{-1}$ ) } & & \multirow{4}{*}{0,284} & & \multirow{4}{*}{0,545} \\
\hline 15 & 3,94 & 5,13 & 5,31 & 3,75 & 4,69 & 4,25 & 4,51 & & & \\
\hline 30 & 4,25 & 4,75 & 4,38 & 4,56 & 5,13 & 4,38 & 4,57 & & & \\
\hline Mean & $4,09 \mathrm{a}$ & $4,94 a$ & $4,84 a$ & $4,16 \mathrm{a}$ & $4,91 \mathrm{a}$ & $4,31 \mathrm{a}$ & & & & \\
\hline
\end{tabular}

${ }^{1}$ Dose of nitrogen; ${ }^{2}$ defoliation intensity; ${ }^{3}$ Interaction between dose of intensities. Means followed by the same letter, upper case in columns and lower case in rows, do not differ by Duncan test $(\mathrm{P}>0.05)$.

However, even when the leaves of gamba grass increase in length they still have a relatively narrow width, which in some ways is disadvantageous because the weight of the leaves can make their position change from erect to flat. Indeed, the number of live leaves per tiller (NLLT) was not significantly influenced $(\mathrm{P}>0.05)$ by the nitrogen level or cutting height, but the gamba grass showed great potential for tillering (Figure 2). The NLLT is defined genetically and is practically unchanged in the absence of water and nutritional deficiencies. These data corroborate the results of Fagundes et al. (2006), who observed that the NLLT of marandu grass was not influenced by nitrogen fertilization, but differed from the results of Martuscello et al. (2005), wherein the NLLT increased proportionally to the level of nitrogen applied.

It should be emphasized that the FLL is influenced by the length of the leaf, and consequently the culm. Oliveira et al. (2007), in a study of morphogenesis in Tanzania grass fertilized with different combinations of $\mathrm{N}, \mathrm{P}$, and $\mathrm{K}$ and under two intensities of cutting, observed a positive correlation between the FLL and pseudostem length. This influence is related to the distance over which the leaf is covered, and, therefore, protected by the sheath from the time of its insertion in the axial yolk to the time of its emergence. This means that the length of the leaf sheath (stem) is proportional to the duration of the cell multiplication phase (FLL) (DURU; DUCROCQ, 2000). However, the difference in the FLL could not be explained by the culm lengths observed in the treatments evaluated in this study (Table 4) because the SER decreased with increased levels of nitrogen fertilization. Even in this context, the differences in the LBL observed could be explained by the fact that this characteristic of a given forage species is somewhat constant, having limited variability within a species and being genetically determined. Therefore, despite the differences observed, the actual LBL of plants that received nitrogen showed little the scale of centimeters.

\section{CONCLUSION}

The recommended fertilization for gamba grass is $286.52 \mathrm{~kg} \mathrm{~N} \mathrm{ha}^{-1}$ year $^{-1}$, and the intensity of defoliation should keep it at a height of $30 \mathrm{~cm}$. In this way, this grass can be optimally exploited in intensive production systems in pastures managed for the maximum efficiency of the forage produced. 
RESUMO: Objetivou-se avaliar as características morfogênicas, produtivas e estruturais do Andropogon gayanus cv. Planaltina submetido a níveis de adubação nitrogenada e intensidades de desfolha. O delineamento experimental foi o inteiramente casualizado com arranjo fatorial $6 \times 2$, doses de nitrogênio $(0,100$, 200, 300, 400 e $500 \mathrm{~kg}$ de nitrogênio ha ${ }^{-1}$ ) e intensidades de desfolhas (15 e $30 \mathrm{~cm}$ ). Os dados de produção e estrutura foram agrupados em períodos chuvoso e seco e os de morfogênese analisados somente em função da adubação e intensidade de desfolha. Foi determinada a produção de biomassa de forragem seca total (BFST), massa seca de folhas (MSF), massa seca de colmos (MSC) e massa seca de forragem morta (MSFM). Além dessas variáveis foram avaliadas as características morfogênicas e de perfilhos vivos e mortos. Houve interação $(\mathrm{P}<0,05)$ entre as doses e intensidade de desfolhas para a MSFT, MSF, MSC e MSFM em ambas as fases de avaliação. Observou-se que as taxas de alongamento foliar, aparecimento foliar e comprimento da lâmina foliar aumentaram com a adubação nitrogenada. Por outro lado, a taxa de alongamento do colmo e Filocrono diminuíram com a aplicação das doses crescentes. As intensidades de desfolha não influenciaram $(\mathrm{P}>0,05)$ nas características morfogênicas, assim como a adubação na taxa de senescência foliar e número de folhas vivas por perfilho. O número de perfilhos mortos aumentou de forma linear durante o período chuvoso. Recomendase manejar o capim-andropógon com intensidade de desfolha de $30 \mathrm{~cm}$ e adubação nitrogenada de $286,52 \mathrm{~kg}$ de $\mathrm{N} \mathrm{ha}^{-1} \mathrm{ano}^{-1}$, visando a maior produção.

PALAVRAS-CHAVE: Andropogon gayanus. Período chuvoso. Período seco. Resíduo.

\section{REFERENCES}

ALEXANDRINO, E.; NASCIMENTO JÚNIOR, D.; MOSQUIM, P. R.; REGAZZI, A, J.; ROCHA, F. C. Características morfogênicas e estruturais na rebrotação da Brachiaria brizantha cv. Marandu submetida a três doses de nitrogênio. Revista Brasileira de Zootecnia, v. 33, n. 6, p. 1372-1379, 2004. https://doi.org/10.1590/S1516-35982004000600003

ARAÚJO, R. A.; RODRIGUES, R. C.; COSTA, C. S.; LANA, R. P.; SANTOS, F. N. S.; LIMA, A. J. T.; RODRIGUES, M. M. Forage intake and performance of cattle in silvopastoral systems and monoculture of Marandu in Pre-Amazon region. African Journal of Agricultural Research, v. 11, n. 20, p. 1849 -1857, 2016. 10.5897/AJAR2016.10795

BRÂNCIO, P. A.; EUCLIDES, V. P. B.; NASCIMENTO JÚNIOR, D.; FONSECA, D. M.; ALMEIDA, R. G.; MACEDO, M. C. M.; BARBOSA, R. A. Avaliação de três cultivares de Panicum maximum Jacq. sob pastejo: disponibilidade de forragem, altura do resíduo pós-pastejo e participação de folhas, colmos e material morto.

Revista Brasileira de Zootecnia, v. 32, n. 1, p. 55- 63, 2003. https://doi.org/10.1590/S151635982003000100007

CÂNDIDO, M. J. D.; GOMIDE, C. A. M.; ALEXANDRINO, E.; ALEXANDRINO, E.; GOMIDE, J. A.; PEREIRA, V. E. Morfofisiologia do dossel de Panicum maximum cv. Mombaça sob lotação intermitente com três períodos de descanso. Revista Brasileira de Zootecnia, v. 34, n. 2, p. 338-347, 2005.

https://doi.org/10.1590/S1516-35982005000200007

CANTO, M. W.; CECATO, U.; PETERNELLI, M.; JOBIM, C. C.; ALMEIDA JÚNIOR, J.; RIGOLON, L. P.; WATFE, E.; BARRIONUEVO, C. V.; NUNES, B. R. C. Efeito da altura do capim-tanzânia diferido nas características da pastagem no período do inverno. Revista Brasileira de Zootecnia, v. 30, n. 4, p. 1186-1193, 2001. https://doi.org/10.1590/S1516-35982001000500008

CASTAGNARA, D. D.; MESQUITA, E. E.; NERES, M. A.; OLIVEIRA, P. S. R.; ZOZ, T.; ZOZ, A. Morphogenesis and production of tanzânia, mombaça and mulato grasses under nitrogen fertilization.

Bioscience Journal, v. 30, p. 45-54, 2014. 
DIFANTE, G. S; EUCLIDES, V. P. B.; NASCIMENTO JUNIOR, D.; SILVA, S. C.; TORRES JÚNIOR, R. A. A.; SARMENTO, D. O. L. Ingestive behaviour, herbage intake and grazing efficiency of beef cattle steers on Tanzania guinea grass subjected to rotational stocking managements. Revista Brasileira de Zootecnia, v.38, n. 6, p. 1001-1008, 2009. https://doi.org/10.1590/S1516-35982009000600005

DURU, M.; DUCROCQ, H. Growth and senescence of the successive leaves on a Cocksfoot tiller. Effect of nitrogen and cutting regime. Annals of Botany, v. 85, p. 645-653, 2000. 10.1006/anbo.1999.1117

FAGUNDES, J. L.; FONSECA, D. M.; MISTURA, C.; MORAIS, R. V.; VITOR, C. M. T.; GOMIDE, J. A.; NASCIMENTO JUNIOR, D.; CASAGRANDE, D. R.; COSTA, L. T. Características morfogênicas e estruturais do capim-braquiária em pastagem adubada com nitrogênio avaliadas nas quatro estações do ano.

Revista Brasileira de Zootecnia, v. 35, n. 1, p. 21-29, 2006. https://doi.org/10.1590/S151635982006000100003

GARCEZ NETO, A. F.; NASCIMENTO JUNIOR, D.; REGAZZI, A. J.; FONSECA, D. M.; MOSQUIM, P. R.; GOBBI, K. F. Respostas morfogênicas e estruturais de Panicum maximum cv. Mombaça sob diferentes níveis de adubação nitrogenada e alturas de corte. Revista Brasileira de Zootecnia, v. 31, n. 5, p. 1890- 1900, 2002. https://doi.org/10.1590/S1516-35982002000800004

LAVRES JR., J.; FERRAGINE, M. D. C.; GERDES, L.; RAPOSO, R. W. C.; COSTA, M. N. X.; MONTEIRO, F. A. Yield components and morphogenesis of aruana grass in response to nitrogen supply. Scientia Agrícola, v.61, n.6, p.632-639, 2004. https://doi.org/10.1590/S0103-90162004000600011

MAGAlHÃES, J. A.; CARNEIRO, M. S. C. S.; ANDRADE, A. C.; PEREIRA, E. S.; ANDRADE, A. P.; BAKKE, O. A.; RODRIGUES, B. H. N.; MOCHEL FILHO, W. J. E.; COSTA, N. L. Características morfogênicas e estruturais do capim-andropógon sob irrigação e adubação. Semina Ciências Agrárias, v. 34, n. 5, p. 2427-2436, 2013. 10.5433/1679-0359.2013v34n5p2427

MARTUSCELLO, J. A.; FONSECA, D. M.; NASCIMENTO JUNIOR, D.; SANTOS, P. M.; RIBEIRO JUNIOR, J. I.; CUNHA, D. N. F.; MOREIRA, L. M. Características morfogênicas e estruturais do capimxaraés submetido à adubação nitrogenada e desfolhação. Revista Brasileira de Zootecnia, v. 34, n. 5, p. 14751482, 2005. https://doi.org/10.1590/S1516-35982005000500007

MORAIS, R. V.; FONSECA, D. M.; NASCIMENTO JÚNIOR, D.; RIBEIRO JUNIOR, J. I.; FAGUNDES, J. L.; MOREIRA, L. M.; MISTURA, C.; MARTUSCELLO, J. A. Demografia de perfilhos basilares em pastagem de Brachiaria decumbens adubada com nitrogênio. Revista Brasileira de Zootecnia, v. 35, n. 2, p. 380-388, 2006. 10.1590/S1516-35982006000200007

MOREIRA, L. M.; MARTUSCELLO, J. A.; FONSECA, D. M.; MISTURA, C.; MORAIS, R. V.; RIBEIRO JÚNIOR, J. I. Perfilhamento, acúmulo de forragem e composição bromatológica do capim-braquiária adubado com nitrogênio. Revista Brasileira de Zootecnia, v. 38, n. 9, p. 1675-1684, 2009.

https://doi.org/10.1590/S1516-35982009000900006

OLIVEIRA, A. B.; PIRES, A. J. V.; NETO, U. M.; CARVALHO, G. G. P.; VELOSO, C. M.; SILVA, F. F. Morfogênese do capim-Tanzânia submetido a adubações e intensidades de corte. Revista Brasileira de Zootecnia, v.36, n.4, p.1006-1013, 2007. https://doi.org/10.1590/S1516-35982007000500004

POMPEU, R. C. F. F.; CÂNDIDO, M. J. D.; LOPES, M. N.; GOMES, F. H. T.; LACERDA, C. F.; AQUINO, B. F.; MAGALHÃES, J. A. Características morfofisiológicas do capim-aruana sob diferentes doses de nitrogênio. Revista Brasileira de Saúde e Produção Animal, v. 11, n. 4, p. 1187-1210, 2010.

SERAFIM, V. F. Manejo do pastejo para capim-andropógon - revisão de literatura. Revista científica de medicina veterinária, n. 24, 2015. 
SILVA, D. R. G.; COSTA, K. A. P.; FAQUIN, V.; OLIVEIRA, I. P.; BERNARDES, T. F. Doses e fontes de nitrogênio na recuperação das características estruturais e produtivas do capim-marandu, Revista Ciência Agronômica, v. 44, n. 1, p. 184-191, 2013.

SOUSA, B. M. L.; NASCIMENTO JÚNIOR, D.; SILVA, S. C.; MONTEIRO, H. C. F.; RODRIGUES, C. S.; FONSECA, D. M.; SILVEIRA, M. C. T.; SBRISSIA, A. F. Morphogenetic and structural characteristics of andropogon grass submitted to different cutting heights. Revista Brasileira de Zootecnia, v.39, n.10, p.21412147, 2010. https://doi.org/10.1590/S1516-35982010001000006

ZANINE, A. M.; SANTOS, E. M.; FERREIRA, D. J. Senescência e acumulo liquido de forragem. Revista Científica Rural, v. 12, n. 2, p. 113-125, 2007. 